\title{
Benign Eye Neoplasm
}

National Cancer Institute

\section{Source}

National Cancer Institute. Benign Eye Neoplasm. NCI Thesaurus. Code C4780.

A non-metastasizing neoplasm that affects the structures of the eye (conjunctiva,

cornea, uvea, retina), the lacrimal gland, and the eyelid. 